\title{
Survey Potensi PeMbangkit Listrik Tenaga Mikro hidro DI KUTA MALAKa KabUPATEN ACEH BESAR Propinsi NANGgRoE ACEH DARUSSALAM
}

\author{
Ridwan Arief Subekti \\ Pusat Penelitian Tenaga Listrik dan Mekatronik - LIPI \\ Komp LIPI Bandung, Jl. Sangkuriang, Gd. 20. Lt. 2, Bandung, \\ Jawa Barat 40135, Indonesia \\ ridwanarief_rais@yahoo.com
}

Diterima: 25 Juni 2010; Direvisi: 30 Agustus 2010; Disetujui: 29 September 2010; Terbit online: 10 Oktober 2010.

\begin{abstract}
Abstrak
Generator set adalah salah satu alat yang dapat menghasilkan listrik. Generator set digunakan bila pasokan listrik PLN tidak mencukupi atau bahkan tidak ada. Hal inilah yang dialami di wilayah Kuta Malaka Kabupaten Aceh Besar - NAD yang rencananya akan dikembangkan menjadi objek wisata. Karena belum tersedianya pasokan listrik dari PLN, maka untuk menunjang kebutuhan listriknya masih menggunakan generator set. Rencananya kawasan wisata tersebut akan memanfaatkan pembangkit listrik tenaga air sebagai sumber pasokan energi listrik. Dari latar belakang tersebut di atas, maka survey potensi air dilakukan dengan tujuan untuk mendapatkan data dan informasi awal potensi tenaga air sebagai dasar dalam perencanaan dan pembangunan PLTMH. Survey potensi ini meliputi penentuan lokasi dan pengukuran head menggunakan global positioning system merek Garmin tipe GPSMAP 76CSx. Selain menggunakan altimeter, pengukuran beda ketinggian juga dilakukan secara manual menggunakan meteran dengan metode spirit level and string. Pengukuran debit air sungai dilakukan dengan mengukur kecepatan arus sungai menggunakan propeller devices atau current meters merek Flowatch. Dari data survey potensi PLTMH di daerah Kuta Malaka tersebut dapat diketahui bahwa terdapat tiga lokasi yang memiliki potensi untuk dikembangkan sebagai lokasi PLTMH dengan head efektif 5 sampai 16 meter dan daya keluaran 3,7 sampai 9,1 kW.
\end{abstract}

Kata Kunci : Energi Air, Mikro Hidro, Pembangkit Listrik, Survey Potensi, Turbin Air.

\begin{abstract}
Generator set is one of the devices able to produces electrics. Generator set used when electrics supply of PLN insufficient or even there no. This matter experienced in Kuta Malaka, Aceh Besar, Nanggroe Aceh Darussalam there will be developed a tour area. Because electrical supply from PLN not yet, power electric to support the area used generator set. Future, that tour area apply hydro power station for electrical energy requirement. From that background, the purpose of water potential survey was conducted to get beginning data and information of water power potential as reference to develop PLTMH. The potential survey cover determination of location and head measurement use global positioning system Garmin GPSMAP 76CSx. The other using altimeter, head also was measure manually used the meter by spirit level and string method. The river rate of flow measurement within measuring to speed of rivers flow use propeller devices or current meters brand Flowatch. From data of PLTMH potential survey in Kuta Malaka area known that there are three potential locations able to be developed as PLTMH with effective head 5 until 16 meter and output power 3.7 until $9.1 \mathrm{~kW}$.
\end{abstract}

Keyword: Water Energy, Micro Hydro, Power Station, Potential Survey, Water Turbine.

\section{Pendahuluan}

\section{A. Latar Belakang}

Listrik merupakan salah satu kebutuhan yang sangat penting bagi kehidupan manusia. Tanpa adanya listrik, akan sulit bagi kita untuk mengembangkan suatu aktivitas. Salah satu contohnya terdapat di wilayah kawasan hutan lindung Kuta Malaka Kabupaten Aceh Besar Propinsi Nanggroe Aceh Darussalam. Di areal hutan lindung seluas kurang lebih 2000 hektar ini, rencananya akan dikembangkan menjadi daerah objek wisata alam.

Saat ini di daerah hutan lindung Kuta Malaka telah dibangun perkebunan buah naga, stroberi, pisang, pohon jati dan lain-lain. Selain itu terdapat pula kolam ikan serta peternakan ayam dan sapi. Bangunan kafe dan kantor administrasi juga sedang dilaksanakan pembangunannya. Rencana kedepan, di areal kawasan hutan lindung Kuta Malaka tersebut juga akan dibangun sarana outbound, kolam pemancingan dan sarana-sarana rekreasi lainnya [1]. 
Namun demikian, karena belum tersedianya pasokan listrik dari PLN, maka objek wisata alam tersebut mengalami beberapa hambatan dalam pembangunannya. Aktivitas perkebunan, peternakan dan objek wisata lainnya akan sulit berkembang tanpa adanya pasokan listrik yang memadai walaupun saat ini seluruh operasional kebutuhan listrik di daerah tersebut masih disuplai oleh generator set. Dengan berkembangnya objek wisata tersebut maka kebutuhan akan energi listrik juga akan terus berkembang sehingga pemakaian generator set yang saat ini digunakan untuk mensuplai listrik menjadi tidak efisien dan boros. Untuk itu, rencananya kawasan wisata di areal hutan lindung Kuta Malaka akan memanfaatkan pembangkit listrik ramah lingkungan yaitu Pembangkit Listrik Tenaga Mikro Hidro (PLTMH) sebagai sumber pasokan energi listriknya. Selain digunakan untuk beberapa tempat objek wisata, listrik yang dihasilkan oleh Pembangkit Listrik Tenaga Mikro Hidro ini juga akan digunakan sebagai penerangan jalan menuju lokasi objek wisata tersebut. Sumber air untuk Pembangkit Listrik Tenaga Mikro Hidro akan memanfaatkan aliran sungai yang terdapat di kawasan hutan lindung Kuta Malaka yang mana menurut penduduk sekitar dan pengelola kawasan tersebut selama ini debit air sungai yang mengalir di Kuta Malaka relatif stabil sepanjang tahun.

Dari latar belakang tersebut di atas, diperlukan suatu survey potensi sungai di daerah kawasan hutan lindung Kuta Malaka sehingga dapat digunakan sebagai sumber energi pada
Pembangkit Listrik Tenaga Mikro Hidro secara optimal.

PLTMH adalah suatu pembangkit listrik tenaga air dengan kapasitas sistem maksimal 120 $\mathrm{kW}$. Hal ini mengadopsi standar kualitas dari India dan Nepal serta mempertimbangkan kemampuan produksi di dalam negeri [2]. Pembangkit listrik tenaga air adalah suatu bentuk perubahan tenaga dari tenaga air dengan ketinggian dan debit tertentu menjadi tenaga listrik, dengan menggunakan turbin air dan generator [3].

\section{B. Tujuan}

Tujuan makalah ini adalah memberikan gambaran dan informasi awal mengenai potensi tenaga air sebagai dasar dalam perencanaan dan pembangunan Pembangkit Listrik Tenaga Mikro Hidro (PLTMH). Dalam makalah ini akan dijabarkan mengenai lokasi-lokasi yang potensial untuk dikembangkan sebagai pembangkit listrik tenaga mikro hidro, potensi daya, spesifikasi turbin, generator, sistem kontrol dan beban serta dimensi pipa penstok dan bangunan sipilnya.

\section{Metode Survey}

Survey potensi Pembangkit Listrik Tenaga Mikro Hidro ini dilaksanakan di daerah pegunungan Kuta Malaka, Kabupaten Aceh Besar Propinsi Nanggroe Aceh Darussalam dengan koordinat $5,2^{\circ}-5,8^{\circ} \mathrm{LU}$ dan $9,50^{\circ}$ $95,8^{\circ}$ BT. Lokasi tersebut seperti yang terlihat pada Gambar 1 di bawah ini yang berasal dari peta program Garmin Map Source.

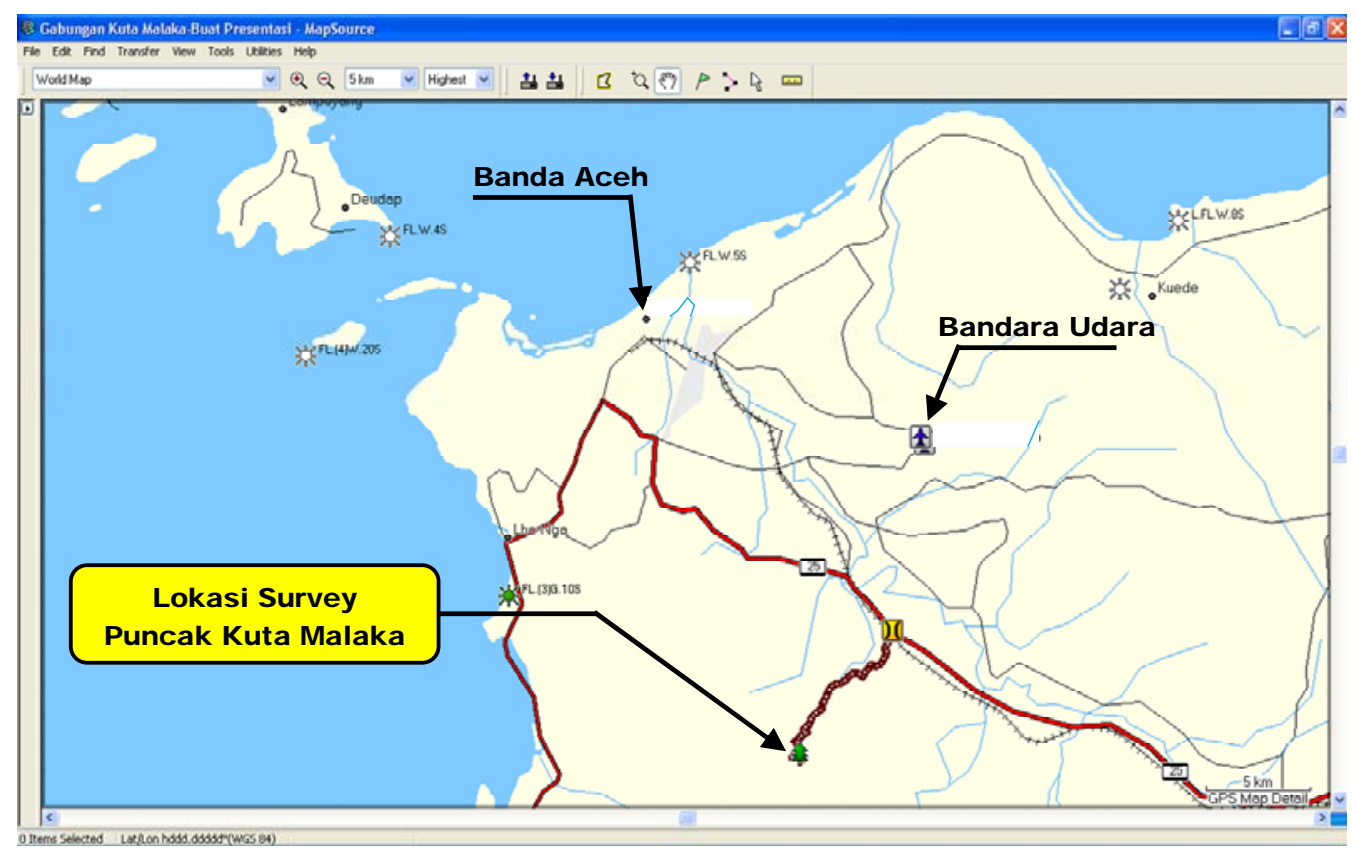

Gambar 1. Peta lokasi survey potensi Pembangkit Listrik Tenaga Mikro Hidro. 
Survey potensi air sebagai dasar dalam perencanaan dan pembangunan Pembangkit Listrik Tenaga Mikro Hidro (PLTMH) ini dilakukan dalam empat tahapan metode seperti dibawah ini:

a. Penentuan lokasi

b. Pengukuran tinggi jatuh air

c. Pengukuran debit air

d. Perhitungan potensi daya terbangkitkan.

Selanjutnya metode survey tersebut akan dijabarkan lebih detail seperti yang terdapat di bawah ini.

\section{A. Penentuan Lokasi}

Penentuan lokasi dilakukan dengan menyusuri sungai yang berada di daerah Kuta Malaka Kabupaten Aceh Besar Propinsi Nanggroe Aceh Darussalam. Survey lapangan dilakukan guna mengetahui lokasi-lokasi mana yang berpotensi untuk dilaksanakan pembangunan Pembangkit Listrik Tenaga Mikro Hidro (PLTMH). Setelah didapat lokasi yang memiliki potensi, dilakukan penandaan lokasi menggunakan GPS seperti Gambar 2 di bawah ini.

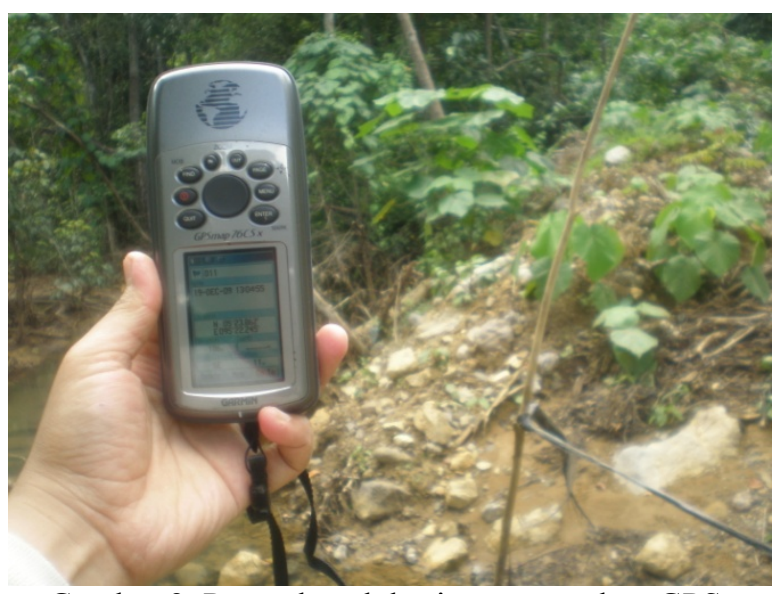

Gambar 2. Penandaan lokasi menggunakan GPS

Tipe GPS yang digunakan adalah GPSMAP76CSx merek Garmin. Pada saat pertama kali kita menghidupkan GPS, receiver GPS secara otomatis akan mengumpulkan data satelit dan arah lokasinya. Untuk memastikan pengenalan yang tepat, GPSMAP76CSx telah dilengkapi dengan mode pencari jejak otomatis. Mode tersebut menunjukkan lokasi GPS di mana saja di seluruh dunia. Untuk menerima sinyal satelit kita harus berada di luar ruangan dan pemandangan langit yang jelas. Waypoint (titik tuju) adalah adalah lokasi yang kita rekam dan simpan di dalam GPS.

Untuk merekam jalur saluran pembawa dari bendungan ke bak penampungan dan jalur pipa penstock dari bak penampungan ke rumah turbin, kita dapat memanfaatkan fitur tracks yang terdapat pada GPS. Fitur tracks menciptakan jejak remah-remah elektronik atau "catatan jejak" pada map page selama bepergian. Catatan jejak tersebut berisi informasi tentang poin-poin sepanjang jalurnya, termasuk waktu, lokasi, ketinggian, dan kedalaman. Catatan jejak segera mulai merekam semua informasi yang diperlukan sesaat setelah alat ini menentukan posisi lokasi yang dikirimkan oleh minimal dua sinyal satelit [4].

\section{B. Pengukuran Tinggi Jatuh Air}

Pengukuran tinggi jatuh air antara sumber air dengan lokasi turbin dilakukan menggunakan altimeter yang terdapat pada GPS. Prinsip kerja altimeter adalah mengukur tekanan udara. Tekanan udara akan berubah $9 \mathrm{~mm}$ head air raksa untuk setiap 100 meter perubahan elevasi. Altimeter sangat mudah terpengaruh oleh perubahan suhu, tekanan atmosfir dan kelembaban. Penggunaan altimeter yang terbaik adalah dengan melakukan pengukuran beda ketinggian dalam jangka waktu yang secepatnya. Secara umum pengukuran menggunakan altimeter adalah pengukuran yang paling baik terutama untuk pengukuran kondisi-kondisi tertentu misalnya untuk pengukuran head yang tinggi.

Altimeter Page pada GPS menunjukkan peningkatan yang sedang berlaku, rata-rata penurunan/pendakian, profil perubahan peningkatan ketinggian sepanjang jarak dan waktu, atau profil perubahan tekanan sepanjang waktu. GPSMAP76CSx ini juga bergantung pada tekanan barometric pada saat menentukan ketinggian dan tekanan pada setiap ketinggian dapat berubah-ubah.

Pengukuran ketinggian juga dilakukan dengan metode pengukuran lainnya sebagai pembanding. Untuk itu, selain menggunakan altimeter, pengukuran beda ketinggian juga dilakukan secara manual menggunakan meteran dengan menggunakan metode spirit level and string (papan water pass). Metode ini hampir sama dengan pengukuran beda ketinggian menggunakan selang water pass namun perbedaanya adalah pada metode spirit level and string menggunakan batang water pass. Metode spirit level and string melakukan pengukuran beda ketinggian antara dua titik dengan menggunakan bantuan tiang, tali, dan batang water pass untuk melihat kelurusannya secara horizontal [5]. Pengukuran head secara manual menggunakan meteran ditunjukkan pada Gambar 3 berikut ini. 


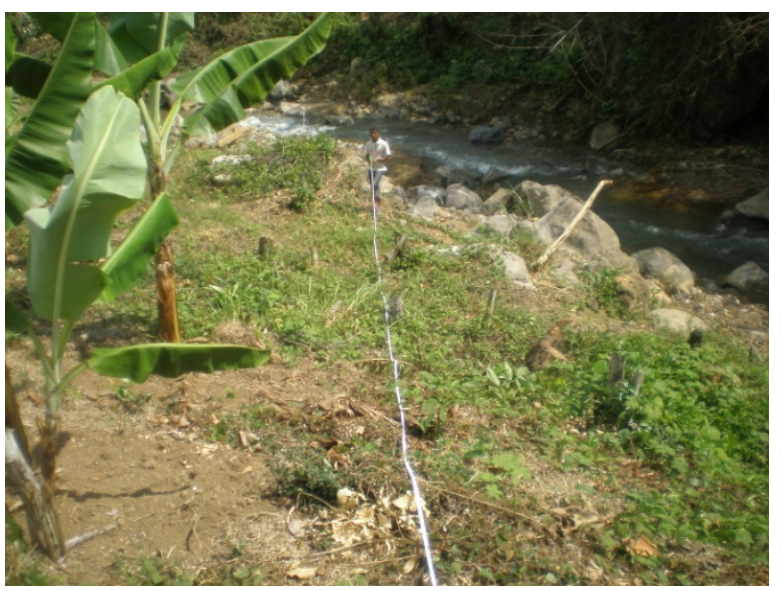

Gambar 3. Pengukuran head menggunakan meteran.

\section{Pengukuran Debit Air}

Pengukuran debit air sesaat di lokasi memilik tiga tujuan yaitu :

a. Untuk mengetahui debit air sepanjang musim kemarau dimana studi hidrologi dilakukan guna mengetahui debit air terkecil

b. Untuk memverifikasi data yang diperoleh dari dokumen pengairan apakah sesuai dengan data yang diperoleh dari pengukuran

c. Diperlukan dalam aplikasi dari metode korelasi aliran.

Pengukuran debit air dilakukan menggunakan alat propeller devices atau sering juga disebut current meters seperti yang terlihat pada Gambar 4 di bawah ini.

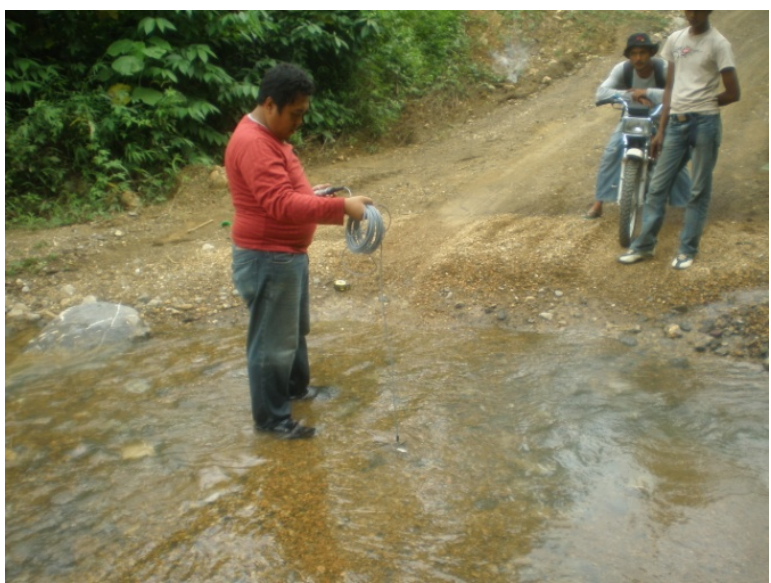

Gambar 4. Pengukuran kecepatan aliran air.

Propeller devices atau current meters adalah sebuah batang dengan propeller atau balingbaling yang dapat bergerak bebas berputar dan dihubungkan dengan layar monitor menggunakan kabel untuk membaca kecepatan aliran air. Biasanya alat ini mengukur kecepatan air mulai dari 0,2 sampai $5 \mathrm{~m} / \mathrm{s}$ dengan tingkat kepresisian $2 \%$. Setelah kecepatan arus air diketahui selanjutnya dilakukan pengukuran luas penampang melintang sungai. Dari dua parameter tersebut, debit air dapat dihitung dengan persamaan berikut.

$$
Q=v \cdot A
$$

Dimana:

$$
\begin{array}{ll}
Q & =\text { debit air }\left[\mathrm{m}^{3} / \mathrm{s}\right] \\
v & =\text { kecepatan air }[\mathrm{m} / \mathrm{s}] \\
A & =\text { luas penampang melintang sungai }\left[\mathrm{m}^{2}\right]^{[6]}
\end{array}
$$

Pengukuran kecepatan aliran air yang mengalir di sungai dilakukan menggunakan alat current meters merek Flowatch. Propeller yang digunakan berdiameter $60 \mathrm{~mm}$ yang dapat mengukur kecepatan air dari $0,2 \mathrm{~m} / \mathrm{s}$ sampai dengan $14 \mathrm{~m} / \mathrm{s}$ dengan tingkat kepresisian $\pm 2 \%$ dan off-axis error $= \pm 20 \%$ sampai $\pm 3 \%$ [7].

\section{Perhitungan Potensi Daya Terbangkitkan}

Data hasil survey potensi air diolah untuk mengetahui besarnya daya yang dapat dibangkitkan dengan menggunakan persamaan (2) berikut.

$$
P=\rho \cdot g \cdot Q \cdot H_{e f f}
$$

$$
\begin{aligned}
& \text { Dimana: } \\
& P \quad=\text { daya terbangkitkan (Watt) } \\
& \rho \quad=\text { massa jenis air }=1000 \mathrm{~kg} / \mathrm{m}^{3} \\
& g \quad=\text { gravitasi }=9,81 \mathrm{~m}^{2} / \mathrm{s} \\
& Q \quad=\text { debit }\left(\mathrm{m}^{3} / \mathrm{s}\right) \\
& H_{\text {eff }}=\text { tinggi efektif }(\mathrm{m})[8]
\end{aligned}
$$

\section{HASIL SURVEY}

Pada kegiatan survey potensi air ini, penentuan lokasi dilakukan dengan mempertimbangkan bebarapa hal seperti letak lokasi yang dekat dengan jalan dan jarak antara lokasi dengan beban (konsumen) sehingga tidak dilakukan penyusuran seluruh aliran sungai. Selain itu juga didapat masukan dari masyarakat sekitar mengenai adanya potensi tenaga air berupa terjunan pada aliran sungai tersebut.

Dari hasil survey potensi air dapat diketahui bahwa lokasi yang potensial untuk dibangun PLTMH memiliki head efektif 5 dan 16 meter. Namun demikian sebenarnya terdapat beberapa lokasi lainnya yang dapat dimanfaatkan untuk membangkitkan listrik yaitu dengan menggunakan turbin head sangat rendah dimana head yang ada sekitar \pm 1 meter.

Pada survey potensi energi air ini dapat ditentukan tiga lokasi yang memiliki potensi untuk dikembangkan sebagai Pembangkit Listrik Tenaga Mikro Hidro seperti disebut dibawah ini. 


\section{A. Lokasi Kesatu - Taeyeun}

Lokasi turbin kesatu terletak didaerah Taeyeun dengan ketinggian 112 mdpl. Lokasi pertama ini berada pada koordinat $5,40559^{\circ} \mathrm{LU}$ dan $95,37636^{\circ}$ BT. Dilokasi Taeyeun ini, head effektif yang dapat dimanfaatkan adalah 5 meter dengan debit terukur $0,23 \mathrm{~m}^{3} / \mathrm{s}$ sehingga potensi daya hidrolis yang dimiliki adalah $9,81 \mathrm{~kW}$. Lokasi rumah turbin, bak pemampungan dan bendungan dapat dilihat pada Gambar 5 .

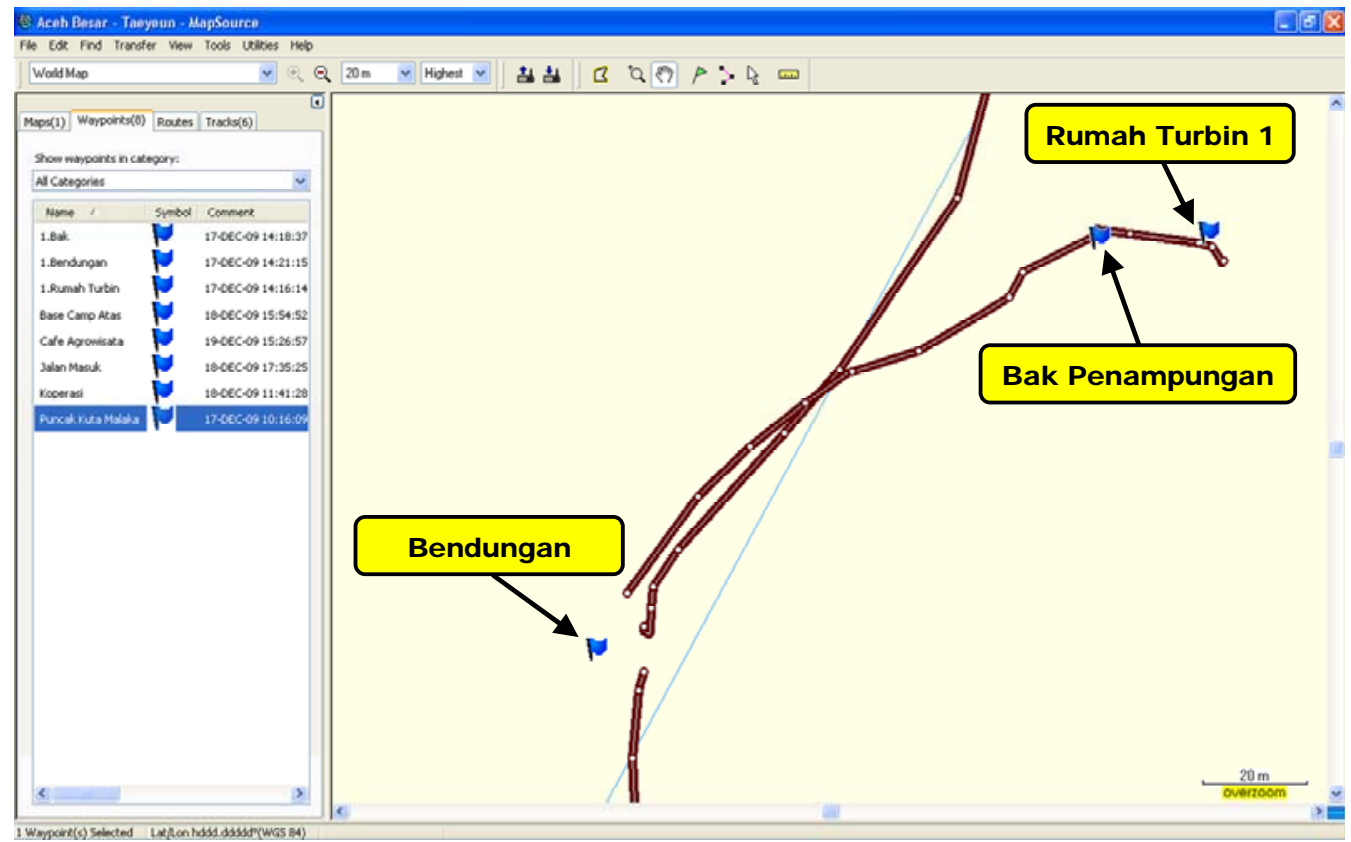

Gambar 5. Posisi turbin, bak penampungan dan saluran pembawa lokasi kesatu.

\section{B. Lokasi Kedua - Kolam Pemancingan}

Lokasi turbin kedua yang terletak di dekat kolam pemancingan diantara bangunan kafe dan lokasi turbin kesatu memiliki ketinggian 177 meter diatas permukaan laut. Lokasi ini berada pada koordinat 5,39894 ${ }^{\circ} \mathrm{LU}$ dan $95,37096^{\circ} \mathrm{BT}$. Dilokasi kedua atau dekat kolam pemancingan ini, head efektif yang dapat dimanfaatkan sama dengan lokasi kesatu yaitu 5 meter namun lokasi kedua ini memiliki debit terukur yang lebih kecil yaitu $0,144 \mathrm{~m}^{3} / \mathrm{s}$ sehingga potensi daya hidrolis yang dimiliki juga lebih kecil bila dibandingkan dengan lokasi kesatu. Potensi daya hidrolis yang dimiliki oleh lokasi kedua ini adalah $6,38 \mathrm{~kW}$. Lokasi turbin kedua dapat dilihat pada Gambar 6 di bawah ini.

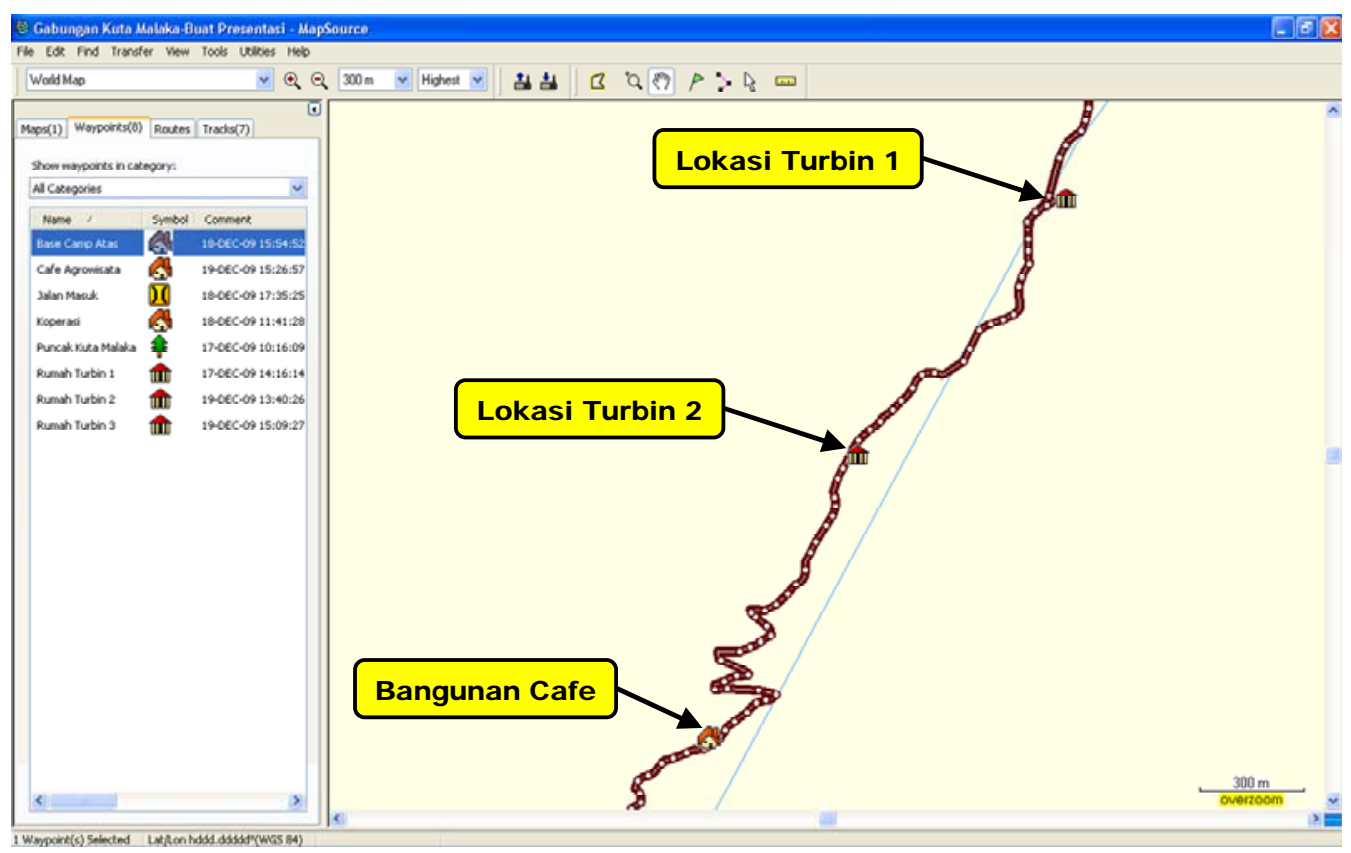

Gambar 6. Lokasi turbin kedua. 


\section{Lokasi Ketiga - Penyeberangan Terakhir}

Lokasi turbin ketiga berada pada koordinat $5,38602^{\circ}$ LU dan $95,36496^{\circ}$ BT. Lokasi ini terletak di dekat penyebrangan terakhir dengan ketinggian 465 meter diatas permukaan laut. Dibandingkan dengan dua lokasi sebelumnya, lokasi ketiga ini memiliki head paling tinggi yaitu 16 meter. Namun demikian, lokasi ketiga ini memiliki debit air terukur yang paling kecil yaitu $0,11 \mathrm{~m}^{3} / \mathrm{s}$. Dengan debit terukur sebesar itu, lokasi ini mempunyai potensi daya yang dapat dibangkitkan sebesar 15,7 kW. Lokasi turbin ketiga dapat dilihat seperti pada Gambar 7 di bawah ini.

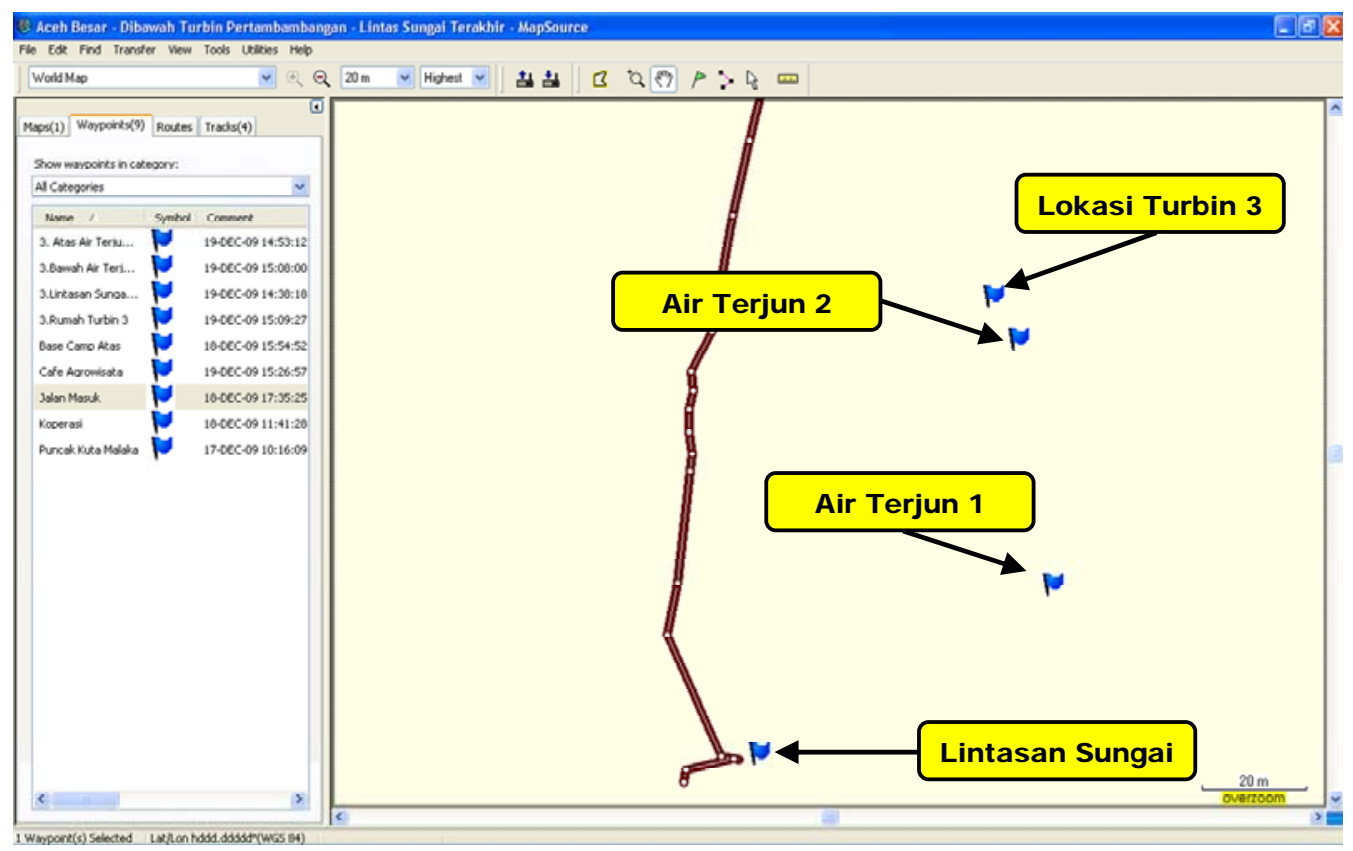

Gambar 7. Lokasi air terjun dan rumah turbin ketiga.

Selanjutnya data survey potensi air dan spesifikasi Pembangkit Listrik Tenaga Mikro Hidro (PLTMH) seperti head, debit, dan besarnya potensi daya yang dapat terbangkitkan untuk setiap lokasi dibuat dalam bentuk tabel seperti pada Tabel 1 dan Tabel 2 dibawah ini.

Tabel 1.

Potensi daya, dimensi penstock dan saluran pada lokasi 1, 2 dan 3 .

\begin{tabular}{|c|c|c|c|c|c|c|}
\hline \multirow{2}{*}{ No } & \multirow{2}{*}{ Uraian \& simbol } & \multirow{2}{*}{ Keterangan } & \multicolumn{3}{|c|}{ Lokasi } & \multirow{2}{*}{ Satuan } \\
\hline & & & 1 & 2 & 3 & \\
\hline 1 & Head efektif $\left(\mathrm{H}_{\mathrm{eff}}\right)$ & & 5,0 & 5,0 & 16 & meter \\
\hline 2 & Debit terukur $\left(\mathrm{Q}_{\mathrm{m}}\right)$ & & 0,23 & 0,144 & 0,11 & $\mathrm{~m}^{3} / \mathrm{s}$ \\
\hline 3 & Debit desain $\left(\mathrm{Q}_{\mathrm{d}}\right)$ & & 0,2 & 0,130 & 0,10 & $\mathrm{~m}^{3} / \mathrm{s}$ \\
\hline 4 & Potensi daya Hidrolis $\left(\mathrm{P}_{\mathrm{h}}\right)$ & $\left(\rho \cdot g \cdot Q_{d} \cdot H_{e f f}\right) / 1000$ & 9,81 & 6,38 & 15,7 & $\mathrm{~kW}$ \\
\hline 5 & Estimasi effisiensi turbin $\left(\eta_{\mathrm{T}}\right)$ & & 80 & 80 & 80 & $\%$ \\
\hline 6 & Estimasi effisiensi total $\left(\eta_{\text {total }}\right)$ & & 58 & 58 & 58 & $\%$ \\
\hline 7 & $\begin{array}{l}\text { Estimasi daya listrik di rumah } \\
\text { pembangkit }(\mathrm{P})\end{array}$ & $\left(\rho . g \cdot Q_{d} \cdot H_{e f f} \cdot \eta_{t o t}\right) / 1000$ & 5,7 & 3,7 & 9,1 & $\mathrm{~kW}$ \\
\hline 8 & Diameter penstock (Ø) & $\operatorname{Kecepatan}(\mathrm{v})=1 \mathrm{~m} / \mathrm{s}$ & 0,5 & 0,4 & 0,4 & $\mathrm{~m}$ \\
\hline 9 & Panjang penstock (L) & Pengukuran & 30 & 30 & 36 & $\mathrm{~m}$ \\
\hline 10 & Panjang saluran pembawa & L: $0,7 \mathrm{~m}$ dan T: $0,75 \mathrm{~m}$ & 130 & 10 & 10 & $\mathrm{~m}$ \\
\hline 11 & Panjang bendungan & Pengukuran & 10 & 10 & 10 & $\mathrm{~m}$ \\
\hline 12 & Bak penampung & $\mathrm{P}: 9,2 ; \mathrm{L}: 3,5 ; \mathrm{T}: 3,5 \mathrm{~m}$ & 1 & 1 & 1 & LS \\
\hline 13 & Saluran pelimpah & L: $0,7 \mathrm{~m}$ dan T: $0,75 \mathrm{~m}$ & 1 & 1 & 1 & LS \\
\hline 14 & Pintu air & L: $0,7 \mathrm{~m}$ dan T: $0,75 \mathrm{~m}$ & 3 & 3 & 3 & pcs \\
\hline
\end{tabular}


Tabel 2.

Spesifikasi turbin, generator, sistem kontrol dan ballast load lokasi 1, 2 dan 3.

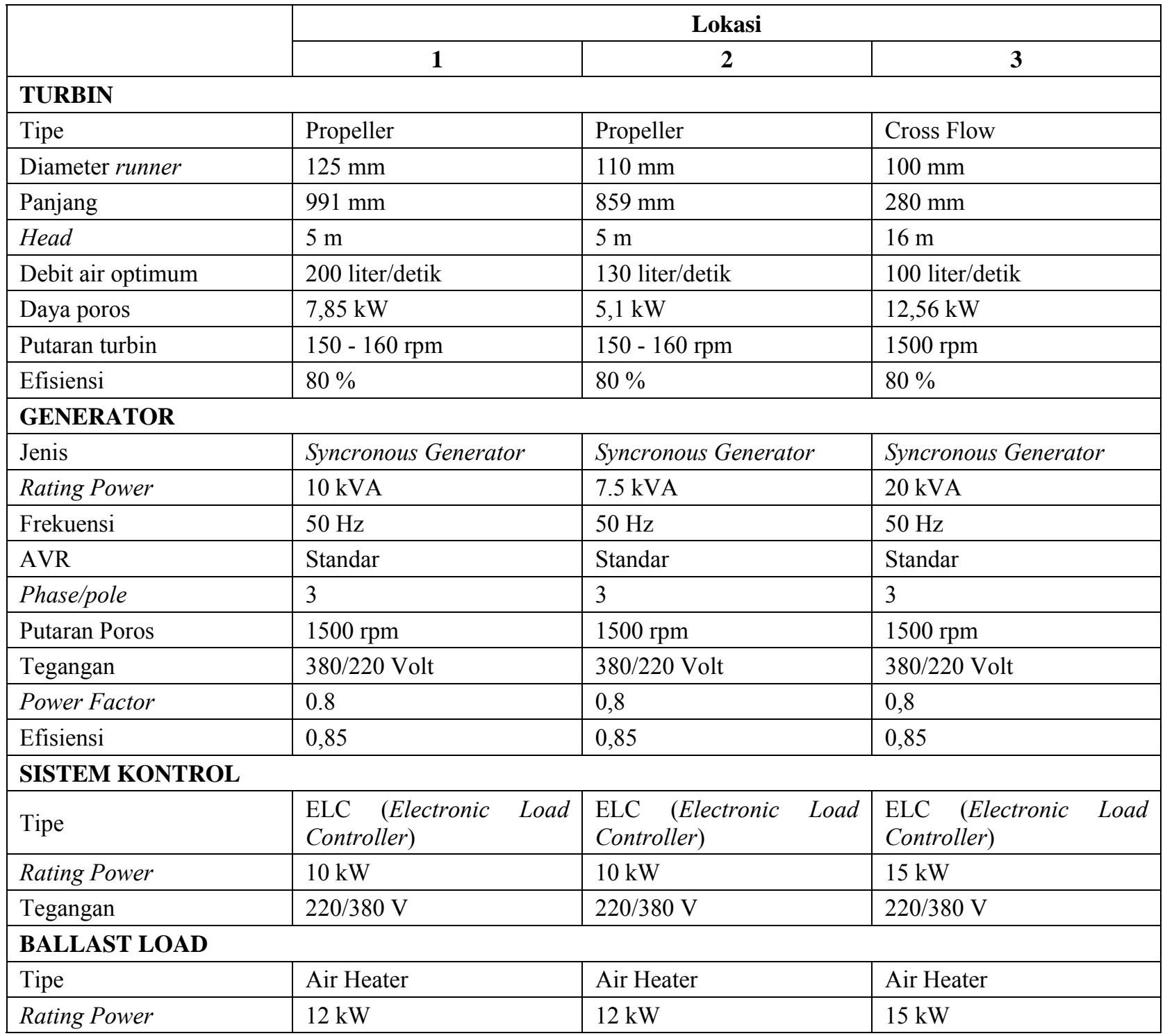

\section{KESIMPULAN DAN SARAN}

\section{A. Kesimpulan}

Dari hasil survey awal yang telah dilakukan di daerah pegunungan Kuta Malaka, Kabupaten Aceh Besar Propinsi Nanggroe Aceh Darussalam, dapat diambil beberapa kesimpulan sebagai berikut:

1. Aliran sungai di kawasan pengunungan Kuta Malaka dapat dimanfaatkan sebagai sumber energi untuk pembangunan Pembangkit Listrik Tenaga Mikro Hidro, baik itu untuk head yang tinggi maupun untuk head yang rendah.

2. Dari hasil perhitungan diperoleh besarnya daya yang mampu dibangkitkan oleh masingmasing Pembangkit Listrik Tenaga Mikro Hidro adalah berbeda disetiap lokasi tergantung head, debit air dan jenis turbin yang digunakan. Hasil perhitungan pada setiap lokasi adalah sebagai berikut.

a. Lokasi 1 : Daya terbangkitkan $5,7 \mathrm{~kW}$ dengan head $5 \mathrm{~m}$, debit $0,2 \mathrm{~m}^{3} / \mathrm{s}$, jenis turbin propeller

b. Lokasi 2 : Daya terbangkitkan $3,7 \mathrm{~kW}$ dengan head $5 \mathrm{~m}$, debit $0,13 \mathrm{~m}^{3} / \mathrm{s}$, jenis turbin propeller

c. Lokasi 3 : Daya terbangkitkan $9,1 \mathrm{~kW}$ dengan head $16 \mathrm{~m}$, debit $0,1 \mathrm{~m}^{3} / \mathrm{s}$, jenis turbin cross flow.

\section{B. Saran}

1. Potensi mikro hidro masih dapat dieksplorasi lebih banyak lagi melalui survey lanjutan terutama memanfaatkan potensi head rendah.

2. Perlunya survey lanjutan sebagai dasar informasi yang lebih akurat guna menyusun studi kelayakan sebelum dilakukannya pembangunan PLTMH. 


\section{UCAPAN TERIMA KASIH}

Terima kasih kami ucapkan kepada Bapak Anjar Susatyo selaku mantan Kepala Bidang Elektronika Daya dan Mesin Listrik, Pusat Penelitian Tenaga Listrik dan Mekatronik Lembaga Ilmu Pengetahuan Indonesia. Terima kasih juga kepada Jon Kanidi, Ibu Pudji, Dodiek, Pak Emin selaku rekan survey dan Bapak Wawan dari PT. Buana Wahana Energi. Terima kasih kepada mas Priyo dan Jainudin atas masukannya. Terima kasih juga kami ucapkan kepada warga Kuta Malaka, Aceh Besar Nanggroe Aceh Darussalam yang telah membantu dalam peraksanaan survey potensi Pembangkit Listrik Tenaga Mikro Hidro ini.

\section{Daftar Pustaka}

[1] _.., "Laporan Survey Potensi Energi Kawasan Pegunungan Kuta Malaka Kabupaten Aceh Besar Propinsi Nanggroe Aceh Darussalam", (2009), PT. Buana Wahana Energi, Bandung.

[2] Kusdiana, D., Sitompul, A. dkk., "Pedoman Teknis Standardisasi Peralatan dan Komponen Pembangkit Listrik Tenaga
Mikro hidro (PLTMH) - Imidap (Integrated Microhydro Development and Application Program)", (2008), Direktorat Jenderal Listrik dan Pemanfaatan Energi Departemen Energi dan Sumber Daya Mineral, Jakarta.

[3] Arismunandar, A. dan Kuwahara, S., "Buku Pegangan Teknik Tenaga Listrik Jilid I Pembangkitan dengan Tenaga Air", (1974), Pradnya Paramita, Jakarta.

[4] _.., "Manual Book GPSMAP 76CSx", (2006), Garmin International Ltd, Kansas, USA.

[5] Harvey, Adam., "Micro Hydro Design Manual - A Guide to small scale water power schemes", (1993), ITDG Publishing, London,UK.

[6] Streeter, V. L. dan Benyamin, E. Wylie., "Mekanika Fluida", Edisi Delapan, Jilid 1, (1986), Erlangga, Jakarta

[7] .., "Instruction Manual of Flowatch", (2006), JDC Electronics SA, Switzerland.

[8] Dietzel, F. dan Sriyono, D., "Turbin Pompa dan Kompresor”, (1990), Erlangga, Jakarta. 